[Jpn. J. Hosp. Pharm.

$\left[\begin{array}{l}\text { 缷 } \\ \left.\text { 18(3) } 282-287(199)^{\prime}\right)\end{array}\right]$

\title{
信州大学病院における注射用抗生物質の使用状況と臨床分離菌の変遷 ${ }^{1}$
}

長井克浩 $\uparrow^{2}$, 太田 伸 ${ }^{* 2}$, 大久保吉弘 $\uparrow^{2}$, 跡部 治 $\dagger^{2}$, 全田 $\quad$ 浩 $\dagger^{2}$, 川上由行 $\dagger^{3}$

信州大学医学部附属病院薬剤部 $\dagger^{2}$ 信州大学医学部附属病院中央検査部 $\dagger^{3}$

\section{Relationships between Quantity of Antibiotics Used for Injection and Changes of Isolated Pathogenic Microorganisms at Shinshu University Hospital $\dagger^{1}$}

\author{
KATSUHIRO NAGAI ${ }^{2}$, SHIN OHTA*2, YoshIHIRO OHKUBO ${ }^{2}$, OSAMU \\ ATOBE $\dagger^{2}$, HIROSHI ZENDA $\dagger^{2}$, YOSHIYUKI KAWAKAMI $\dagger^{3}$ \\ Department of Pharmacy ${ }^{2}$, Central Clinical Laboratories ${ }^{3}$, \\ Shinshu University Hospital
}

( $\left.\begin{array}{l}\text { Received July 23, } 1991 \\ \text { Accepted November 30, 1991) }\end{array}\right)$

\begin{abstract}
We investigated quantity of antibiotics used for injection and the changes of clinically isolated microorganisms during the period from April 1986 to September 1990 at Shinshu University Hospital. The aim of this study was to clarify the relationship between occurrence of drug resistant bacteria and quantity of antibiotics-injection used. It was found that 1) the number of clinically isolated Staphylococci has been increasing year by year, 2) the 3rd generation cephalosporins were the most used agents among the antibiotics during these period, 3) frequency of isolation of Staphylococci was recognized to be relatively high at the clinical area where the 3rd generation cephalosporins were consumed in large quantities.
\end{abstract}

Keywords_-antibiotics injection; pathogenic microorganisms; Staphylococci; 3rd generation cephalosporins; MRSA

\section{は じめに}

感染症の化学療法として用いられる抗生物質と 合成抗菌剂の開発は目覚ましいものがあり,その 種類と品目数は年毎に増加している.それにとも ない薬剤を使用する者にとって，その選択はむず かしいものとなっており使い分けを常に考慮しな くてはならない. 特に, 感染症の起炎菌の変遷と 共に薬剤耐性菌の出現が治療をいっそら困難にし ている.その中で, 近年メチシリン耐性ブドウ球

$\dagger^{1}$ 本報は日本薬学会第111年会（東京, 1991年 3 月） で発表.

$\dagger^{2,3}$ 長野県松本市旭 3-1-1; 3-1-1, Asahi, Matsumoto-shi, Nagano, 390 Japan
菌（MRSA）による感染症が増加しており, 治療 上大きな問題となっている1-7).

この MRSA の蔓延は, 第 3 世代セフェム系抗 生物質が万能の化学療法剂と誤認され繁用された のが一因とされている。このように使用薬剤によ って特定の細菌が猛威をふるらことは, 安易な薬 剂選択に警告を発しているとも思われる，当院で も多くの抗菌剂が採用されており, 特に第 3 世代 セフェム系は購入品目数も購入高も全抗菌剤の中 で最も大きな割合を占めている.

我々は, 先に抗生物質の使用状況について報告 した ${ }^{8)}$. 今回は抗生物質の中でも特に注射用抗生 物質に的をしぼり, 今後の抗生物質の適切な選択 や耐性菌発現の早期発見に役立てることを目的と 
して, 信州大学医学部附属病院に打ける過去 4 年 6 力月間の注射用抗生物質の使用状況之臨床分離 菌の変遷との関係を調查したので報告する.

\section{調査期間と方法}

当院は診療科数 19 科, ベッド数 680 床の病院で ある。調查期間は1986年 4 月 1 日より1990年 9 月 30 日までの 4 年 6 力月間で抗覀性腫瘍抗生物質を 除く注射用抗生物質71品目について，系統別およ び病棟別に分類し，全体の購入量より采統別の使 用状況を，また実際に病棟に払い出された量から 病棟別の使用状況を調查した。

併せて当院中央検査部細菌検查室で分離した入 院患者からの臨床分離株も病棟別に分㺭，注射用 抗生物質の使用状況調査と同様の期間について検 出状況を調査した。

\section{結果}

\section{1. 各種注射用抗生物質の購入品目数}

注射用抗生物質の購入品目数（品目数は同一物 質でも規格が異なっている場合は別に 1 品目とし て数えた.)の年次推移を表 1 亿示した。 セフェム 系は1986年に20品目であったのが1990年には29品 目となり，中でも第 3 世代セフェム系は1986年に 6 品目だったのが，1990年には14品目と 2 倍以上 に増加していた。またアミノグリコシド系は1986 年に12品目であったが1990年には 3 品目増加し, 15品目購入されていた。 カルバペネム系とモノバ

表 1. 注射用抗生物質の購入品目数

\begin{tabular}{l|r|r|r|r|r}
\hline & 1986 & 1987 & 1988 & 1989 & 1990 \\
\hline セフェム系第1世代 & 5 & 5 & 5 & 6 & 6 \\
$\quad$ 第2 2世代 & 9 & 9 & 10 & 7 & 9 \\
第3 世代 & 6 & 7 & 11 & 17 & 14 \\
ペニシリン系 & 16 & 16 & 17 & 17 & 14 \\
アミノグリコシド系 & 12 & 12 & 11 & 15 & 15 \\
マクロライド系 & & 1 & 1 & & \\
テトラサイクリン系 & 1 & 2 & 1 & 2 & 2 \\
カルバペネム系 & & 1 & 1 & 1 & 1 \\
モノバクタム系 & & 1 & 2 & 2 & 2 \\
その他 & 7 & 6 & 5 & 8 & 8 \\
\hline 合 計 & 61 & 68 & 69 & 71 & 69 \\
\hline
\end{tabular}

クタム系は1987年から採用されており，品目数は 1 品目増えたのみであった。他の系の注射用抗生 物質の購入品目数には大きな変動は見られなかっ た.

\section{2. 年度別細菌検出状況と注射用抗生物質の購} 入量

1986年 4 月 1 日から1990年 9 月 30 日までの 4 年 6 力月間の当院中央検査部細菌検査室 で分 離 し た，入院患者からの臨床分離菌の分離頻度の高い 菌種または菌属を含む上位 20 種属を選びその検出 状況を図 1 に示した. Pseudomonas 属, Staphylococcus 属, Enterococcus 属, Candida属の 4 属 が上位を占めており, 他の菌属は数\%の検出状況 であった。

上位 4 菌属について見てみるとPseudomonas 属, Enterococcus 属, Candida属の 3 属は1986年 から1990年を通して10\%から15\%の間の増減で分 離されていたが，1987年以後Staphylococcus 属が 年毎に増加傾向を示し，1990年には $23 \%$ と 1986年 の約 2 倍の分離頻度を示していた.

次に各種注射用抗生物質の購入量の年次推移を $\mathrm{kg}$ 力価として, 図 2 に示した（な利 1990 年度分 は実際購入量の 2 倍の值とした.). 第 3 世代セフ ェム系が，調査期間を通して一番多く購入されて いたが年度毎に減少し1988年以降はほぼ同程度の 購入量であった。第 2 世代セフェム系, ペニシリ ン系，第 1 世代セフェム系の推移は1986年, 1987 年での第 2 世代セフェム系，ペニシリン系の順 が，1988年からは逆の順になっていた。また $198 \overline{8}$ 年からは第 1 世代セフェム系が急激な増加を示し た、モノバクタム系，カルバペネム系は1987年か ら購入され，1988年には増加が見られた。また同 時期にセフェム系全体が減少を示し，モノバクタ ム系，カルバペネム系に取って代わった感があっ たが1988年以後は減少あるいは横這い傾向であっ た.

図 3 に1989年と1990年の 2 年間の実際に病棟に 払い出された各種抗生物質の使用本数を示した. 第 3 世代セフェム系，ペニシリン系，第 2 世代セ フェム系, 第 1 世代セフェム系の順であり, 購入 量を $\mathrm{kg}$ 力価で表した図 2 と同様な順番であっ 


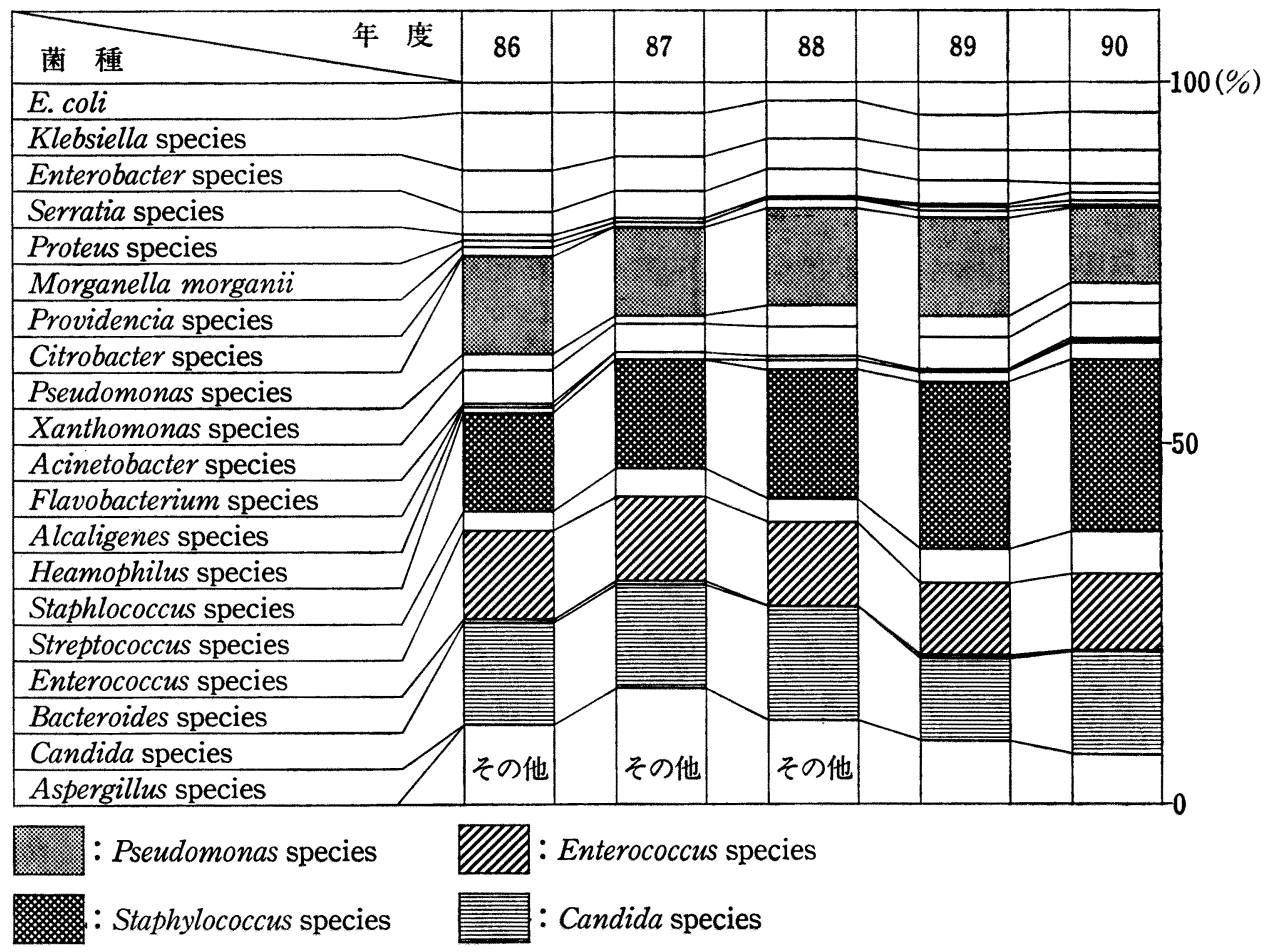

図1. 年度別細菌検出状況

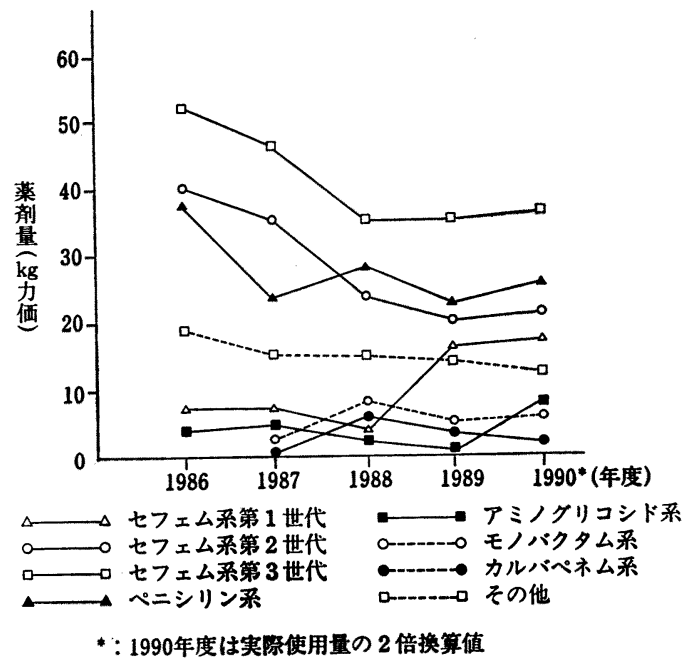

図 2. 注射用抗生物質の年度別購入量

た. またアミノグリコシド系は1989年から1990年 の 1 年間で 1.5 倍の使用量の増加を示した.

\section{3. 病棟別注射用抗生物質使用量と細菌分離状} 況
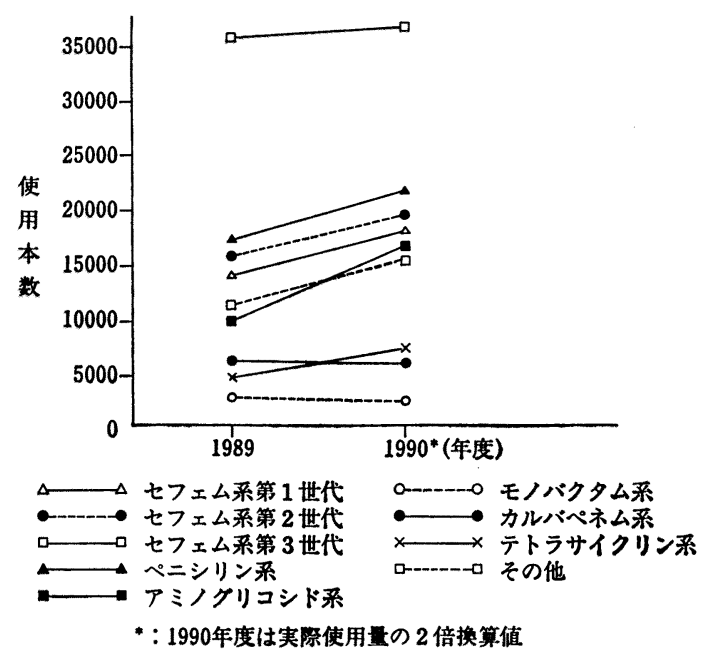

図 3. 全病棟に拈ける使用本数

10 診療科（1 病棟約 40 床）について病棟別の使 用量を $\mathrm{kg}$ 力価として図 4 に示した. 耳鼻・形成 外科が1986年, 1987年, 1990年と最も使用量が多 く, ついで消化器, 心臓外科を中心とする第 2 外 
科, 肝臓, 消化器, 循環器疾患を中心とする第 2 内科, 呼吸器, 循環器疾患を中心とする第 1 内科 の順であった。1990年には整形外科掞よび白血病 治療を主としている小児科が，他の病棟に比べは っきりとした増加を示した．次に病棟別に，特に セフェム系とペニシリン系を選び，各々の使用量 を図 $5(\mathrm{a})$ ，(b)に示した。

耳鼻・形成外科はペニシリン系，七フェム系共 に1987年を境に使用量が減少しており，1990年の 使用量は1986年に比べ約30\%減少していた。消 化器, 心臓外科を中心とする第 2 外科はセフェム 系では1989年までは横這いの使用量であったが， 1990年には1989年に比べ約15\%減少した。整形外 科，小児科は図 4 に示したように，抗生物質全体 の使用量は1989年から1990年にかけて急激に増加 をしているが，これをセフェム系，ペニシリン系 に分けてみると，小児科ではセフェム系 $39 \%$ ， ペ ニシリン系 $67 \%$ の增加, 整形外科では, セフェム系 $17 \%$ ，ペニシリン系 $72 \%$ の増加と，両科ともにペ ニシリン系の使用量が増加していた。特に整形外 科は1989年までセフェム系の使用量に比べペニシ リン系の使用量が 1 番低かったことより，今後そ の動向が注目される.

呼吸器, 循環器を中心とする第 1 内科は1986年 から1990年まで全調査期間を通してペニシリン系 の使用量が $3 \mathrm{~kg}$ から $4 \mathrm{~kg}$ と他の診療科に比べて 多かった。その他の科に関しては特徴的な現象は 見られなかった。

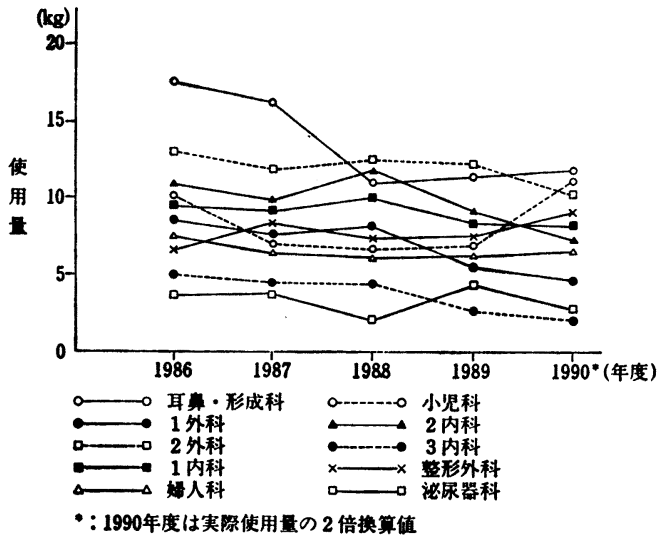

図 4. 病棟別注射用抗生物質使用量

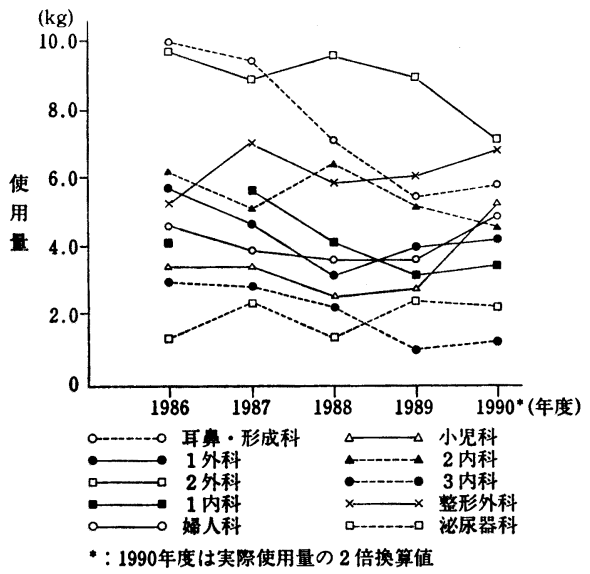

図 5(a). 注射用抗生物質の病棟別使用量(セフェム系)

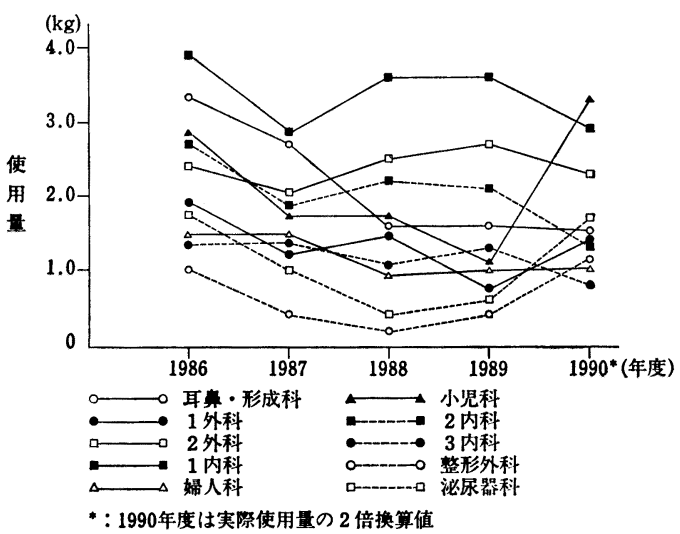

図 $5(b)$. 注射用抗生物質の病棟別使用量(ペニシリン系)

図 6, 図 7 に調查期間の最初の1986年度と最後 の1990年の診療科別細菌分離状況を示した. 各 診療科とも Staphylococcus 属の分離頻度が 非常 に多くなってきていることが注目された。また， 1986年には 分離頻度の低かった Streptococcus 属 が, 消化器, 心蔵外科を中心とする第 2 外科およ び整形外科，耳鼻・形成外科に目立って多く分離 されるよらになった。

\section{考察}

近年のセフェム系抗生物質の開発は目覚ましい ものがあり，1962年（1965年発売）に第 1 世代七 フェム系抗生物質セファロリジン (CER) が世に 出て，1972年(1984年発売)には第 2 世代セフェム 系抗生物質セファマンドールナトリウム(CMD) 


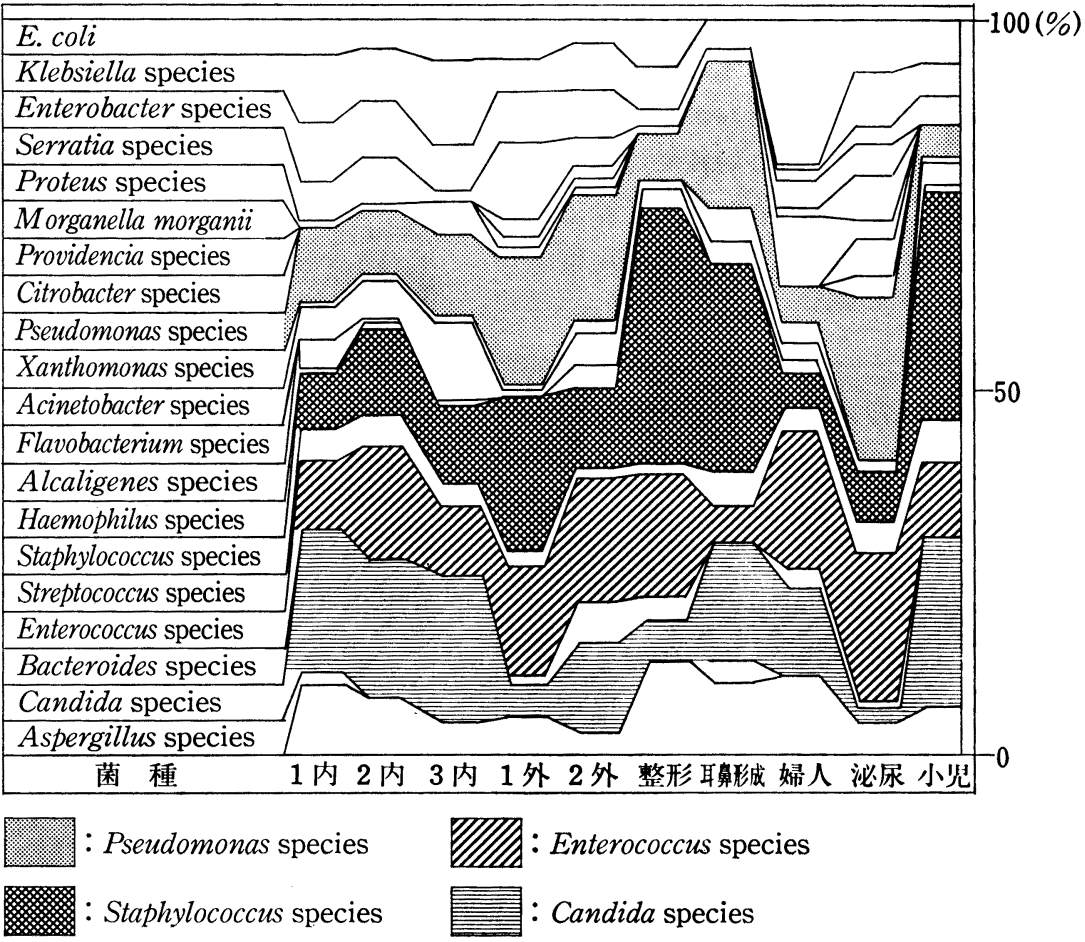

図6.1986年度科別細菌検出状況

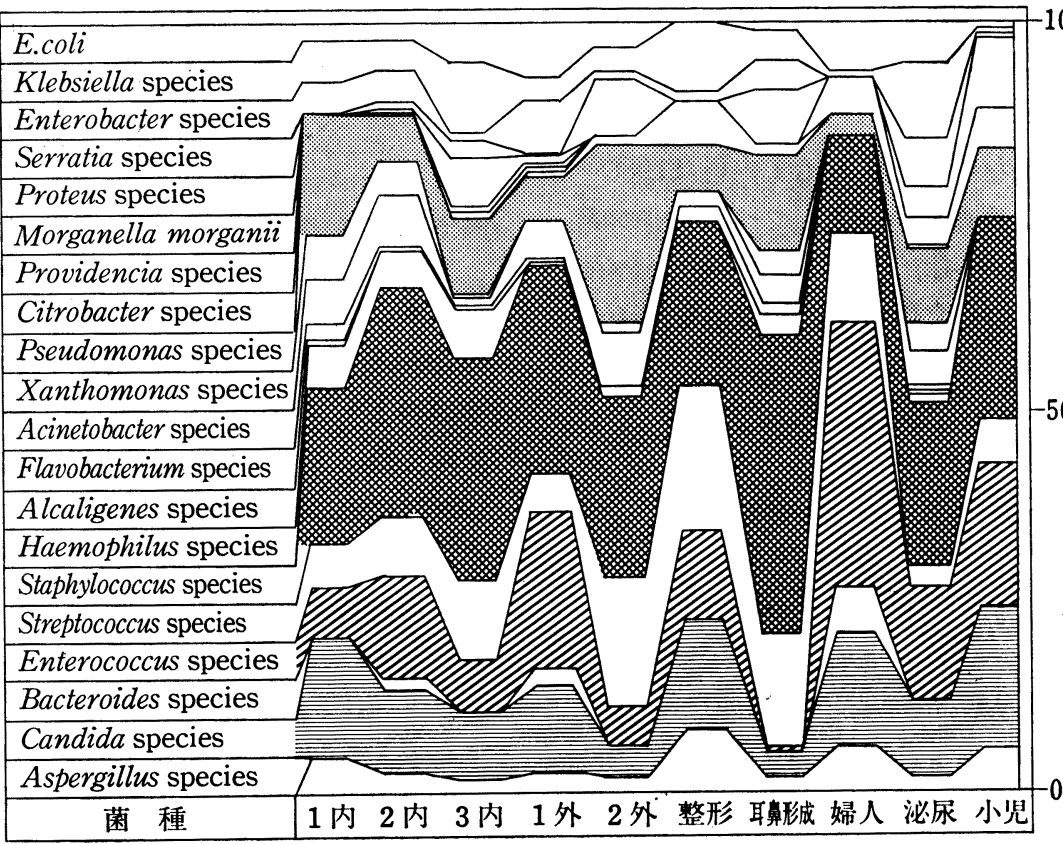

: Pseudomonas species

: Staphylococcus species

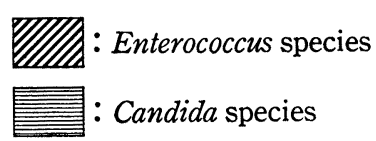

図7. 1990 年度科別細菌検出状況 
が，そして1977年（1981年発売）にセフォタキシ ムナトリウム (CTX) をはじめとする多くの第 3 世代セフェム系が続々と発売されてきている9 . これらの中には緑膿菌やブドゥ球菌にも有効であ り，かつ製剂技術の向上により血中半減期が延長 されたものなどいくつか注目されるものがある が，今後さらに次の世代のセフェム系の開発が盛 んになると思われる。

今回の調查でセフェム系抗生物質の購入量が年 毎に減少していることが明らかになった．特に第 3 世代セフェム系抗生物質の減少が著しく，その 理由の一つとして第 3 世代セフェム系抗生物質の 繁用が Pseudomonas 属, Staphylococcus 属の薬 剂耐性菌の出現の理由として考えられたことによ り病棟での使用量が減少し，それにともない全体 の購入量も減少したものと思われる。一方, 臨床 分離菌に注目すると図 7 に示したようにPseudomonas属, Staphylococcus属, Enterococcus 属等 の分離頻度が高く，中でもStaphylococcus 属の 増加が著しい。なお，このことは近年院内感染原 因菌としての MRSA が深刻な問題となっている 折から細菌検査室に持ち込む検体数が増加したこ とも, これらの菌の分離頻度の上昇の原因の一つ と考えられる.

この結果として, Staphylococcus 属に対して第 3 世代セフェム系より感受性が良いペニシリン系 や第 1 世代七フェム系が見直されていることより 使用量扣よび全体の購入量の増加につながったと 考えられる.

また,アミノグリコシド系は第 8 脳神経障害や 腎障害といったかなり重篤な副作用が出るため投 与量の選択が難しく, 単位の異なった注射薬を購 入せざるを得なかったために品目数が増加したと 思われる.さらに最近では抗菌スペクトルの拡 大, 抗菌力の増強等を目的として,セフェム系やぺ ニシリン系と併用して使用される報告もあり1012)，今後アミノグリコシド系は協力的殺菌効果に よる併用療法の面で重要な薬剤となっていくと考 えられる。
おわりに

当院での過去 4 年 6 カ月間の注射用抗生物質の 使用実態と臨床分離菌の変遷との関連について以 下の結果が得られた。第 3 世代セフェム系の使用 量は, 4 年 6 力月間を通して他の抗生物質に比べ 一番多く使用されていたが使用量は1987年以後か なり減少傾向にある. 1986 年から年毎に Staphylococcus 属の分離頻度が増加し, 第 3 世代セフ ェム系の使用量の多い病棟に Staphylococcus 属の 分離頻度が多かった。最近ではペニシリン系, ア ミノグリコシド系等, 他の系統の抗菌剤の使用量 が増加傾向にあることは一時期第 3 世代セフェム 系に対する過剩な信頼感が使用量の増加につなが っていたことを考えると，抗生物質の選択に関し て良い方向に進んでいるとも思われる. 今後もこ れらのデーターを参考として適切な抗生物質の選 択が行われるよう院内啓蒙を図っていくつもりで ある。

\section{引 用 文 献}

1）藤井千穂, 中浜 力, 臨休検查, $34,812-817$ (1990).

2）草野展周，仲宗根勇，臨床病理， 9, 990-997 (1990).

3） 新谷洋三, 医薬ジャーナル，26，271-283 (1990).

4）島田 馨, 外科, 52, 232-234 (1990).

5）柴田達彦, 中山 淳, 川上由行, 金丸 敬, 小田 切徹太郎, 清野誠一, 臨床麻醉, 14, 993-997 (1990).

6）浜野恭一, 桐田孝史, 医薬ジャーナル，26，723728 (1990).

7）松本慶蔵, “MRSA” 松本慶蔵編, 医薬ジャ一 ナル社, 大阪, 1991, pp.11-15.

8）太田 伸, 大久保吉弘, 坪田知明, 全田 浩, 化学療法の領域, 5, 126-132 (1989).

9）橋本一, “セフェム系抗生物質”, 松本慶蔵 編, 医薬ジャ一ナル社, 大阪, 1991, pp. 27-35.

10）島田 馨, 日本臨床, 43，260-264 (1985).

11）增田順一, 藤原真由美, 大場恵津子, 武田憲三, 福田一郎, 奥村和夫, 化学療法の領域, 6, 156 -164 (1990).

12）和田光一, 荒川正昭, 医薬ジャーナル，27，2529 (1991). 